\title{
Miejsce Kontusia z Łowczyc w tradycji religijnej polskich Tatarów
}

DOI: http://dx.doi.org/10.12775/LC.2020.008

\section{Wprowadzenie i nota metodologiczna}

atarzy to grupa etniczna wywodząca się ze Złotej Ordy, której przodkowie byli pierwotnie wyznawcami kultów szamanistycznych, a za czasów panowania chana Uzbeka (Öz Beg), począwszy od I połowy XIV w., przyjmowali islam ( $w$ formie sunnickiej, ale z licznymi elementami sufizmu). Związki Tatarów z Wielkim Księstwem Litewskim zostały zapoczątkowane już pod koniec XIV w. przez uciekinierów, którzy szukali schronienia w trakcie walk o władzę toczonych na obszarze Wielkiego Stepu. Byli to stronnicy odsuniętego od władzy chana Tochtamysza. Sojusz ten okazał się na tyle trwały, że wkrótce muzułmańscy Tatarzy, pod dowództwem chańskiego syna Dżelal al-Dina, zasilili swoimi oddziałami wojska, sprzymierzonych z Polską Litwinów, podczas bitwy z Zakonem Krzyżackim pod Grunwaldem (1410). Pierwsze kolonie tatarskie, które powstawały wokół Wilna w XV w. były zasiedlane przez kolejnych uchodźców (głównie z Krymu) i stały się podstawą osadnictwa na Wileńszczyźnie i Grodzieńszczyźnie (Tyszkiewicz 1986: 110-169).

Tatarzy, w wyniku oddziałującego przez kilkaset lat procesu adaptacji, w pełni zintegrowali się z chrześcijańskim otoczeniem. Porzucili tym samym swoją odrębność narodową i rdzenne dialekty, wyróżniając się poświęceniem w służbie wojskowej dla nowej ojczyzny oraz postawami patriotycznymi. Odrębność etniczną, chroniącą przed zupełną asymilacją - w sytuacji osłabienia dziedzictwa tatarskiego, zaburzenia transmisji tradycyjnych

* Doktor nauk humanistycznych w zakresie socjologii, adiunkt w Katedrze Socjologii Uniwersytetu Warmińsko-Mazurskiego w Olsztynie. Zainteresowania naukowe: problematyka mniejszości etnicznych i narodowych (polscy Tatarzy) oraz obecność islamu w Polsce i Europie.

E-mail: michal.lyszczarz@interia.pl | ORCID: 0000-0002-9200-3123. 
wartości kulturowych i znacznego poziomu polonizacji - zagwarantować Tatarom mogło jedynie przywiązanie do islamu. Religijność tej społeczności nabrała jednakże charakteru etnicznego i niearabskiego (turecka proweniencja islamu Tatarów), a ponadto selektywnego (zubożonego względem ortodoksji koranicznej) i w dodatku synkretycznego (łączącego elementy różnych tradycji muzułmańskich z wpływami chrześcijańskiego otoczenia i tamtejszych tradycji ludowych) (szerzej Łyszczarz 2017a: 224-228).

Postać Kontusia, bohatera niniejszego artykułu, wiąże się nierozerwalnie z Łowczycami - starą kolonią tatarską (osadnictwo od początku XVI w.), położoną nieopodal Nowogródka na Białorusi, która po II wojnie światowej znalazła się poza granicami Polski (szerzej Łyszczarz 2017d: 63-95). W wyniku ustalenia przez zwycięskie mocarstwa ich nowego przebiegu, tradycyjne centra osadnictwa tatarskiego na Litwie i Białorusi zostały włączone do ZSRR. Przesiedlenie części Tatarów do nowych siedzib na tzw. Ziemiach Odzyskanych, w ramach akcji repatriacyjnej, spowodowało jednakże rozproszenie tej niewielkiej społeczności, co nie pozostało bez wpływu na kultywowanie tradycji etnicznych i religijnych oraz osłabienie pamięci o dawnych zwyczajach tej grupy (Łyszczarz 2017b: 31-32).

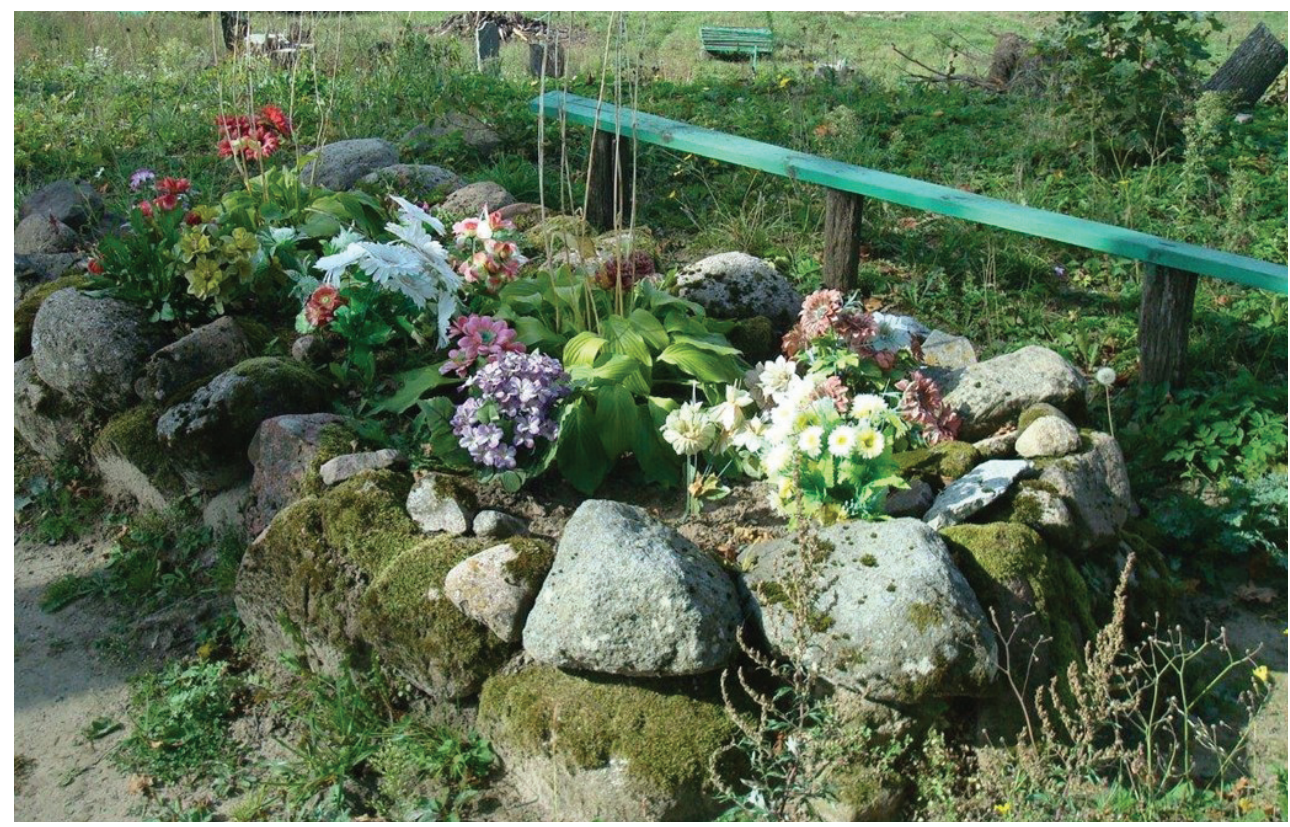

Grób Ewliji Kontusia w Eowczycach w 2017 roku

Archiwum prywatne Joanny Puchalskiej

Niezwykłość Kontusia z Łowczyc bezsprzecznie związana jest $\mathrm{z}$ faktem spisania przez Michała Dmitriewa ${ }^{1}$ tradycji ludowej, która istniała w świadomości Tatarów

\footnotetext{
1 Michał Dmitriew (Михаил Алексеевич Дмитриев) - ur. 1832 w Petersburgu, zm. 1873 w Nowogródku, nauczyciel, dyrektor gimnazjum w Nowogródku, a następnie urzędnik kuratorium (Grodzieńskiej Dyrekcji Szkół Publicznych), etnograf-samouk, jeden z pierwszych badaczy białoruskiego folkloru (https://istp2012.wordpress. com/2017/09/03/dmitriev/).
} 
zamieszkujących okolice Nowogródka. Postać tamtejszego auliji ${ }^{2}$ stanowi jedyny zachowany po dziś dzień przykład tatarskiego kultu świętych. Wielce prawdopodobne jest bowiem to, że na Kresach Wschodnich istniały inne podania, mówiące o życiu i cudach towarzyszących świątobliwym osobom (np. o Szorcu z Bohonik). Nie zostały one jednak spisane, co spowodowało, że praktycznie żaden ślad nie pozostał już po tych, bezpowrotnie zanikających, tradycjach tatarskich. W przypadku Kontusia stało się inaczej. Dzięki temu, że legenda doczekała się druku w „Biuletynie Cesarskiego Rosyjskiego Towarzystwa Geograficznego” w 1859 r. (Dmitrijew 1859: 66-67), a następnie - w wersji bardziej szczegółowej - opublikowana została w gazecie „Kuryer Wileński” z dnia 14 lutego 1861 r. (Dmitrijew 1861a: $111)^{3}$, osoba łowczyckiego auliji została rozpropagowana, a jej znaczenie przekroczyło ramy lokalnego kultu.

W niniejszym artykule autor zamierza przybliżyć znaczenie postaci auliji dla polskich Tatarów. Jest to zadanie trudne, gdyż współczesna wiedza o Kontusiu z Łowczyc - ze względu na dotychczasowy prawie zupełny brak badań terenowych ${ }^{4}$ - opiera się przede wszystkim na wskazanym podaniu, które istniało w świadomości Tatarów. Szczególnie interesujące wydaje się być zagadnienie osobistego stosunku społeczności tatarskiej do łowczyckiego świętego, a także wyjaśnienie powodów niezwykłości grobu Kontusia oraz motywów, którymi kierują się Tatarzy pielgrzymujący do jego grobu.

Przystępując do analizy stosunku polskich Tatarów do postaci Kontusia, autor niniejszego artykułu - bezpodstawnie jak się okazało - przyjął założenie, że osoba auliji z Łowczyc jest powszechnie znana polskim Tatarom. Druga hipoteza badawcza zakładała natomiast, że nawet jeżeli polscy Tatarzy w ograniczony sposób czczą świętego, to na pewno szanują tę postać i mają wiedzę dotyczącą tego, kim on był i w jaki sposób odbywa się kult religijny związany z jego osobą. Innymi słowy autor przekonany był o trwałej obecności Kontusia w świadomości polskich Tatarów jako mitu. Ten typ myślenia odwołuje się do antropologicznej koncepcji, którą przed laty sformułował Bronisław Malinowski. Według słynnego badacza ludów tubylczych na Trobriandach mit wyjaśnia najważniejsze cechy danej zbiorowości (np. stratyfikację społeczną), odnosi się do osób wybitnych (bohaterów), których istnienia nie poddaje się w wątpliwość, a ślady ich istnienia są upamiętnione i nadal widoczne (pomniki, skały). Tak rozumiany mit to opowieść podobna do legendy, lecz nietożsama z nią. W przeciwieństwie do niej, nie należy bowiem całkowicie do świata przeszłości, lecz żyje własnym życiem, które zasadniczo wpływa na sposób strukturalizacji teraźniejszości (Malinowski 1990: 260). Tak postawione założenia badawcze bardzo szybko zostały zweryfikowane po rozpoczęciu badań terenowych. Ku swemu zdziwieniu autor zauważył, że wielu tatarskich rozmówców (zwłaszcza z młodego pokolenia) nie wiedziało nic o Kontusiu albo też ich wiedza zupełnie rozmijała się z treścią legendy, uwiecznionej w połowie XIX w. przez Michała Dmitriewa.

\footnotetext{
2 Aulija (także jako awlija lub ewlija) - legendarna często postać świętego w islamie, obecna głównie w mistycznych nurtach sufickich oraz w lokalnych tradycjach ludowych, osoba pełniąca rolę pośrednika pomiędzy człowiekiem a Bogiem („przyjaciel Allaha”), czego nie akceptują ortodoksyjni teologowie muzułmańscy. Kultowi świętego towarzyszy wiara, że cudowna moc tej osoby utrzymuje się po śmierci i emanuje na wiernych z grobowca (por. Wnuk-Lisowska 2013: 94-104).

3 Polska wersja podania o Kontusiu pojawiła się wkrótce na stronach krakowskiej gazety "Czas" (por. Dmitrijew 1861b: 3).

4 Jedyną w zasadzie próbę zbadania fenomenu kulturowego kultu Kontusia z Łowczyc podjął współcześnie Ryszard Vorbrich (por. Vorbrich 2009: 20-25).
} 
Sądy formułowane w niniejszym artykule opierają się na zrealizowanych przez autora badaniach terenowych w środowisku polskich Tatarów. Mając na względzie wspomnianą ograniczoną świadomość i wiedzę o Kontusiu, uzyskany materiał empiryczny obrazuje przede wszystkim wyobrażenia dotyczące łowczyckiego świętego. Ich katalizatorem w dużej mierze stała się sytuacja wywiadu, w której autor sprowokował respondentów do zastanowienia się nad problematyką, która dotąd - co wykazały badania - nie stanowiła przedmiotu głębszych dociekań. Dla polskich Tatarów rozmowa o Kontusiu była niejednokrotnie inspiracją, zachętą do tego, aby bliżej zainteresować się zapomnianą tradycją własnej grupy. Świadczyć o tym może, wielokrotnie artykułowana przez respondentów, chęć zapoznania się z tekstem legendy o łowczyckim auliji. Symptomatyczny jest także wiersz poświęcony tej świątobliwej osobie, który napisał jeden z Tatarów kilka tygodni po rozmowie przeprowadzonej na potrzeby projektu badawczego ${ }^{5}$. Mając powyższe na względzie, autor ma świadomość, że sytuacja wywiadu mogła w pewnym sensie wpłynąć na charakter uzyskanych wyników. Wypowiedzi respondentów zostały bowiem w dużej mierze wywołane uporem badacza.

Zaprezentowany w niniejszym artykule materiał empiryczny został zebrany dzięki wykorzystaniu techniki pogłębionego wywiadu jakościowego, skategoryzowanego dzięki autorskim dyspozycjom. Wszystkie wywiady zostały przeprowadzone osobiście i zarejestrowane przy pomocy dyktafonu. Do analizy autor wykorzystał materiał empiryczny pochodzący z wywiadów przeprowadzonych z 14 osobami. Procedurą badawczą objęto wyłącznie polskich Tatarów - przedstawicieli jednej z najmniejszych grup etnicznych w Polsce. Dodatkowo wykorzystany został materiał z jednego wywiadu, zrealizowanego z myślą o wcześniejszym projekcie dotyczącym praktyk magicznych polskich Tatarów (por. Łyszczarz 2017c: 93-102). Badania przeprowadzono w kwietniu i maju 2017 r. Dobór próby nie był reprezentatywny - miał charakter celowy, ponieważ badania kierowano do liderów społeczności i ekspertów. Krok ten podyktowany był dostępnością osób, spełniających kryteria doboru próby, a także, wspomnianym już wcześniej, niewielkim poziomem wiedzy członków społeczności tatarskiej w zakresie przedmiotu badania. Wynikiem tego jest nadreprezentacja mężczyzn, seniorów oraz mieszkańców Białegostoku - największego skupiska polskich Tatarów ${ }^{6}$.

\footnotetext{
${ }^{5}$ Mowa o wierszu Musy Çaxarxana Czachorowskiego, rozpoczynającym się od strofy „Za miasteczkiem, na zboczu...", który powstał 13 maja 2017 r. (por. Czachorowski 2018: 214-215).

${ }^{6}$ Lista respondentów: mężczyzna - urodzony w 1955 - zamieszkały w Olsztynie - wywiad przeprowadzony w dniu 09.04.2017 (W 1); M - ur. 1953 - Wrocław - 20.04.2017 (W 2); M - ur. 1979 - Gdańsk - 26.04.2017 (W 3); K - ur. 1937 - Białystok - 11.05.2017 (W 4); M - ur. 1971 - Białystok - 11.05.2017 (W 5); K - ur. 1982 - Białystok 11.05.2017 (W 6); M - ur. 1945 - Białystok - 12.05.2017 (W 7); K - ur. 1952 - Białystok - 11.05.2017 (W 8); M - ur. 1963 - Białystok - 12.05.2017 (W 9); M - ur. 1983 - Suchowola - 13.05.2017 (W 10); M - ur. 1969 - Suchowola 13.05.2017 (W 11); M - ur. 1975 - Białystok - 13.05.2017 (W 12); K - ur. 1932 - Gdańsk - 19.04.2016 (W 13a) oraz 21.05.2017 (W 13b); M - ur. 1941 - Gdańsk - 21.05.2017 (W 14).
} 
Tabela 1. Charakterystyka próby ze względu na płeć, wiek i miejsce zamieszkania (opracowanie własne)

\begin{tabular}{|c|c|}
\hline Pleć & $\begin{array}{c}\text { Próba } \\
\text { N=14 }\end{array}$ \\
\hline Mężczyźni & 10 \\
\hline Kobiety & 4 \\
\hline
\end{tabular}

\begin{tabular}{|c|c|}
\hline Kategoria wiekowa & $\begin{array}{c}\text { Próba } \\
\mathbf{N}=\mathbf{1 4}\end{array}$ \\
\hline $\begin{array}{c}\text { Seniorzy (osoby urodzone } \\
\text { w latach 1932-1955) }\end{array}$ & 7 \\
\hline $\begin{array}{c}\text { Osoby w średnim wieku } \\
\text { (1963-1975) }\end{array}$ & 4 \\
\hline $\begin{array}{c}\text { Młode pokolenie } \\
\text { (1979-1983) }\end{array}$ & 3 \\
\hline
\end{tabular}

\begin{tabular}{|c|c|}
\hline $\begin{array}{c}\text { Miejsce za- } \\
\text { mieszkania }\end{array}$ & $\begin{array}{c}\text { Próba } \\
\text { N=14 }\end{array}$ \\
\hline Białystok & 9 \\
\hline Gdańsk & 3 \\
\hline Olsztyn & 1 \\
\hline Wrocław & 1 \\
\hline
\end{tabular}

\section{Znaczenie Kontusia z Łowczyc dla tożsamości etnicznej polskich Tatarów}

Wspomniany niewielki poziom wiedzy polskich Tatarów o Kontusiu z Łowczyc jest w dużej mierze wynikiem zaniku pamięci o tej postaci, będącej konsekwencją odchodzenia od dawnych tradycji. Proces wypierania ze świadomości przejawów ludowej obrzędowości rozpoczął się - na co wskazują respondenci - wiele lat temu. Przyczyną takiego stanu rzeczy była na pewno II wojna światowa. Nie można jednak pomijać znaczenia globalnych zmian cywilizacyjnych (presji nowoczesności i sekularyzacji), które wpłynęły na osłabienie dotychczasowych związków z tradycją tatarską.

To nie zaczęło się wczoraj. Już przed wojną były symptomy zubożenia tradycji tatarskiej. Nasi działacze to dostrzegali i dlatego podejmowali kroki na rzecz promowania wiedzy o Tatarach. Po wojnie to już była katastrofa. To, że w latach 90. udało się ożywić Tatarów uważam za cud. To był ostatni moment. Jeżeli realia PRL-u potrwałyby jeszcze kilkanaście lat, to nas już by nie było, uleglibyśmy kompletnej asymilacji (W 7).

Tatarscy rozmówcy, z którymi przeprowadzono wywiady, w większości przypadków, deklarowali brak bezpośrednich związków pomiędzy tatarskością, a tradycją związaną z Kontusiem. Zdaniem respondentów przywiązanie do łowczyckiego świętego, lub też jego brak, nie ma wpływu na fakt bycia Tatarem oraz na kształtowanie własnej tożsamości etnicznej. Stosunek do kultywowania dawnych tradycji kresowych ani świadomość istnienia Kontusia nie stanowią zatem kryteriów pozwalających na ocenę charakteru przynależności do społeczności tatarskiej. Powyższe stanowisko potwierdzają poniższe wypowiedzi:

Kontuś jako element tradycji tatarskiej na pewno ma dla mnie jakieś znaczenie, choć niezbyt wielkie. Są przecież ważniejsze przejawy tatarskości (W 7).

Dla mnie ta legenda nie ma jakiegoś większego znaczenia. Taka bajka po prostu. Ciekawostka tatarska (W 10). 
Kontuś na pewno nie był nigdy konstytutywnym elementem naszej tożsamości. To był raczej, mniej lub bardziej istotny, dodatek. Jedni w niego wierzyli, dla innych to była tylko ciekawostka, jeszcze inni zupełnie nie przywiązywali do niego wagi. I ci wszyscy ludzie byli Tatarami i muzułmanami (W 1).

Z przytoczonymi opiniami koresponduje konkluzja, która pojawiła się w wypowiedziach kilkorga osób. Zdaniem Tatarów postać łowczyckiego auliji jest obecnie ważniejsza dla świata nauki, niż dla samej społeczności. Osoba Kontusia stanowić może cel interesujących badań etnograficznych, które ukazywałyby specyfikę tradycyjnej - niegdyś bardzo popularnej - ludowej obrzędowości, ale - z perspektywy współczesnej polskiej rzeczywistości - nie jest już realnie istniejącym zjawiskiem kulturowym i religijnym.

Ciekawe jest to, że teraz ludzie nauki [ ... ] wiedzą więcej o Kontusiu niż przeciętny Tatar (W 4). Kontuś to ciekawostka dla was naukowców, a nie realny przejaw religijności Tatarów (W 5).

Legenda o tatarskim świętym jest uznawana za element tradycji i dziedzictwa przodków, które warto poznać. Respondenci deklarowali zatem zainteresowanie osobą auliji. Takie podejście charakterystyczne jest zwłaszcza dla raczej nielicznej grupy osób, o na tyle mocno rozbudowanej świadomości etnicznej, że przywiązującej wagę nie tylko do poznawania historii własnej społeczności, lecz skupiającej się także na wszystkim tym, co wiąże się z Tatarami.

Dla nas wszystko, co się wiąże z dziedzictwem i kulturą jest ważne. Ja o tym Kontusiu nie wiedziałam nic oprócz tego, że to imię mi gdzieś kiedyś mignęło. Teraz, jak już wiem kim on był, o czym była ta legenda, to ją doceniam (W 9).

Ja wiem o Kontusiu bardzo niewiele. Wiem tylko, że Tatarzy pielgrzymują do Łowczyc i odwiedzają grób Kontusia. [...] Nie wiem na czym cudowność Kontusia polegała. [...] W domu nie mówiło się o nim. Moi rodzice są stąd, z Podlasia. To może dlatego. Dopiero już jako dorosła osoba, jakoś tak przy okazji [ ... ] usłyszałam, że był ktoś taki. Po rozmowie z panem chciałabym się czegoś dowiedzieć, będę musiała do książek zerknąć. Wie pan może, czy gdzieś ta historia jest spisana?" (W 8).

\section{Poziomy zróżnicowania osobistego stosunku do Kontusia}

Stosunek polskich Tatarów do Kontusia z Łowczyc charakteryzować mogą dwie możliwe postawy. Na podstawie opinii zebranych od respondentów wnioskować można, że podejście do tego elementu tradycji przyjmuje biegunowo odmienne formy. Pierwszą z nich określić można mianem „entuzjastycznej”, ponieważ tworzą ją krzewiciele tradycji i tropiciele wszelkich przejawów dawnych zwyczajów. Postawa ta charakterystyczna jest dla starszego pokolenia Tatarów, które zna Kontusia ze wspomnień, opowieści rodzinnych oraz osobistych doświadczeń dzieciństwa w przedwojennej Polsce. „Entuzjaści” to także osoby młodsze, o szczególnie silnej identyfikacji z tatarskością, których wiedza o tradycji ma 
charakter wtórny, gdyż czerpana jest z opracowań naukowych i popularyzatorskich, w których znalazł się tekst legendy ${ }^{7}$.

Pamięć o Kontusiu ograniczona jest do dwóch grup: starszego pokolenia Tatarów, które ma rodzinne korzenie na Białorusi oraz tych wszystkich, którzy chłoną wszystko, co tatarskie. Pierwsi znają Kontusia z opowieści dziadków, ci drudzy z książek. [... ] Ta nasza pierwsza grupa osób, dla których Kontuś jest ważny, czyli seniorzy pochodzący z Kresów, postrzegają tę postać w kategoriach religijnych. To jest taki islam ludowy. Ci drudzy, którzy, że tak powiem, wtórnie zainteresowali się Kontusiem, podchodzą do niego bardziej w kategoriach etnicznych, dla nich Kontuś jest ważny jako element tatarskości (W 2).

Kontuś jest mi bliski, staram się żyć tak, jak moi dziadkowie. Oni szanowali Kontusia, ja także staram się to pielęgnować i przekazywać dalej wnukom (W 4).

Teraz w moc Kontusia wierzą tylko nasi seniorzy. Część z nich jeździ na Białoruś. Są osoby, które były tam kilka razy. [... ] Znam legendę o Kontusiu. Czytałam broszurę z Sagą o Kontusiu (Faizof 2011). Ta legenda była też w Bajkach Selima Chazbijewicza ${ }^{8}$. [...] U nas w Sokółce ta legenda nie była znana. [...] Wiem o Kontusiu dlatego, że sama się tym zainteresowałam. Po prostu udało mi się przeczytać to opowiadanie (W 6).

Drugą postawę, charakteryzującą stosunek polskich Tatarów do Kontusia z Łowczyc, określić można mianem „sceptycznej”. Jest ona typowa dla osób, które mają niewielką wiedzę o tatarskim świętym i w żaden sposób nie starają się jej pogłębić, gdyż nie dostrzegają takiej potrzeby i nie uważają tej postaci za niezwykłą. „Sceptycy” to także ci, szczególnie pobożni Tatarzy, którzy odrzucają kult kresowego auliji z powodów religijnych. Kontuś, jako ludowy przejaw religijności, nie mieści się w tym wypadku w doktrynie islamu i ortodoksji koranicznej. Powyższa postawa charakterystyczna jest głównie dla przedstawicieli młodego i średniego pokolenia. Obrazują ją następujące cytaty:

Młodzi i średnie pokolenie natomiast często nie wie nawet kim jest ten Kontuś. Myślę, że nawet większość spośród nich nie ma najmniejszego pojęcia, z czym to powiązać. Nie słyszeli nic o Kontusiu, bo rodzice i dziadkowie im nie powiedzieli. Nie przeczytali legendy, bo mało kto się naszymi wydawnictwami interesuje (W 6).

7 Legendę o Kontusiu z Łowczyc przytacza R. Vorbrich: „Stefan Batory, przebywając na łowach w okolicy Nowogródka, zatrzymał się obok źródła zwanego srebrzystym. Łowczy królewski wyznania muzułmańskiego, zachwycony urokiem miejsca, wyjednał dla siebie u króla to miejsce, osiedlając się na przyznanych gruntach. [...] Jedyna córka łowczego pod wpływem jezuitów przeszła na katolicyzm. Wówczas łowczy, aby odwrócić gniew Boga (sprzedawszy uprzednio część swych dóbr), wybrał się z ekspiacyjną pielgrzymką do Mekki. Tam jednak skończyły się pieniądze ze sprzedaży majątku. Gdy pogrążony w modlitwie prosił o cud, który wybawiłby go z tak rozpaczliwej sytuacji, pewien pielgrzym doradził mu, aby udał się z prośbą o pomoc do swego ziomka, modlącego się codziennie u grobu Proroka. Jakże ogromne musiało być zdziwienie królewskiego dostojnika, gdy - idąc za radą pielgrzyma - ujrzał tam swego ubogiego pastuszka Kontusia. Ten wyjawił swemu panu (wymógłszy na nim uprzednio przysięgę zachowania tajemnicy do śmierci jednego z nich), iż przybywa tu każdego dnia do Mekki, by zanieść modły do Allaha. Ulegając prośbom łowczego, przeniósł go w cudowny sposób, w jednej chwili, do Łowczyc. Od tego czasu Kontuś otoczony być wielkim szacunkiem i poważaniem łowczego, który zapraszał pastuszka do swego stołu i uznał go za swego pobratymca. Ludzie byli zaintrygowani dziwnym postępowaniem łowczego, zaś pytany o jego powód odpowiadał, że Kontuś zasługuje na szacunek, bowiem jest świętym. Ten stan trwał aż do śmierci Kontusia. Po jego zgonie zjaśniała nocą zorza. Łowczy zaś, uwolniony od przysięgi, opowiedział o cudownej mocy zmarłego. Nad jego grobem wyrosły bez pomocy człowieka dwa potężne dęby. Mogiła świętego została otoczona wielką czcią przez okolicznych muzułmanów, a z czasem sława cudownych uzdrowicielskich właściwości grobu rozeszła się po Wielkim Księstwie Litewskim. Grób stał się celem pielgrzymek" (Vorbrich 2009: 22-23).

8 Respondent ma na myśli opracowanie S. Chazbijewicza (2012). 
Do mnie jakoś nie dociera ta postać. Może dlatego, że słabo znam jej historię. U mnie w rodzinie ta opowieść nie funkcjonowała. Mama jest z Kruszynian, rodzina dziadka z Suchowoli (W 5).

Dla mnie, jak dla większości przedstawicieli młodego pokolenia, Kontuś jest mało znany albo wręcz zupełnie nieznany. Ciężko jest cokolwiek więcej o nim powiedzieć. [...] W przypadku Kontusia rozgraniczam tradycję tatarską i wymogi islamu. W tradycji są ważniejsze elementy niż Kontuś (W 3).

\section{Niezwykłość grobu Kontusia}

Respondentów, z którymi przeprowadzono wywiady, poproszono ponadto o wyjaśnienie przyczyn niezwykłości grobu Kontusia. Ich wskazanie miało dopomóc w ustaleniu powodów, dla których Tatarzy pielgrzymowali do Łowczyc. Według tatarskich rozmówców, mogiła Kontusia postrzegana jest jako: cudowna, anonimowa, skromna, najważniejsza w Łowczycach i magiczna. Cudowność, wspomniana jako pierwsza, wynika z faktu, iż grób nie zarasta chwastami i - pomimo upływu czasu - nie zapada się pod ziemię. W następujących słowach opowiadają o tym respondenci:

Cudowność tego grobu polegać ma na tym, że się nie zapada. Kamienie wyglądają tak, jak gdyby ułożono je całkiem niedawno [W 1 ].

Wiem, że w Łowczycach jest jego grób, na którym nic nie rośnie, a kamienie się nie zapadają w ziemię [W 6].

Anonimowość mogiły Kontusia wiązana jest z brakiem inskrypcji. Jeden z respondentów trafnie zauważył, że napisy (formuły konfesyjne i modlitewne oraz część informacyjna, pozwalająca na identyfikację zmarłego tj. imiona, nazwisko, pozycja społeczna, data śmierci - zob. Drozd 2016: 15-50) pojawiały dopiero na późniejszych upamiętnieniach. W związku z tym, brak epigrafiki nagrobnej, który mógłby stanowić argument podważający wiarę w prawdziwość Kontusia, postrzegany jest jako zaleta, ponieważ pozwala wierzyć w autentyczność przekazu zawartego w legendzie.

Jeżeli ten grób jest tak stary, jak mówi legenda, to aż tak bardzo nie dziwi mnie brak inskrypcji, bo Tatarzy nie umieszczali w XVI w. żadnych napisów. Chociaż, jeżeli Kontuś był tak wyjątkową postacią, to mogliby zrobić wyjątek. Brak napisów jest na pewno wygodny dla tych, którzy wierzą w legendę, bo gdyby jakieś napisy były, to mogłoby się okazać, że tam leży ktoś inny albo - choć to mniej prawdopodobne - że jest to pustostan (W 5).

Trzecim powodem niezwykłości grobu Kontusia jest przekonanie, iż mogiła ta jest bardzo skromna, ale zarazem zadbana. Polscy Tatarzy, z uznaniem, podkreślali w swoich wypowiedziach fakt otoczenia troskliwą opieką tego upamiętnienia przez miejscową społeczność.

Jak byłem tam w latach 90. to cmentarz był dziki, meczet zamknięty, ale mogiła była zadbana. Legenda wiąże to $\mathrm{z}$ cudownością Kontusia, ale tego cudu nie byłoby bez pomocy miejscowych. Mogiła jest na lekkim wzniesieniu, obłożona trzema rzędami kamieni, wypielęgnowana, bez 
trawy i chwastów. Ludzie, którzy ją odwiedzają często kładą na niej wiązanki ciętych kwiatów (W 1).

Grób jest na wzgórzu, skromny ale zadbany, otoczony kamuszkami (W 13b).

Po czwarte, mogiła Kontusia jest postrzegana jako najważniejszy grób, spośród tych, które znajdują się na mizarze ${ }^{9} \mathrm{w}$ Łowczycach. Tatarscy rozmówcy podkreślają, że o randze tego upamiętnienia świadczy fakt, że bez najmniejszego problemu do auliji trafi każdy wierny, który tylko odwiedzi cmentarz. Na taki stan rzeczy wpłynęły zmiany infrastrukturalne związane z wyznaczeniem drogi, która prowadzi od meczetu do pobliskiego grobu Kontusia. Ten namacalny przejaw postępu cywilizacyjnego jest jednakże krytycznie oceniany przez respondentów, co potwierdza poniższa wypowiedź:

[... ] muszę ci powiedzieć, że ostatnie zmiany na cmentarzu w Łowczycach nie bardzo mi się podobają. Od bramy wejściowej aż po sam grób Kontusia wylano beton. Teraz już nie trzeba szukać grobu, każdy do niego trafi, ale dawny klimat przepadł (W 11).

Niektórzy respondenci, jako ostatnią przyczynę niezwykłości grobu Kontusia, wskazywali ponadto magiczne właściwości przypisywane tej mogile. Wśród Tatarów (zwłaszcza przedstawicieli, „entuzjastycznego” wobec tej tradycji, starszego pokolenia) obecna jest bowiem wiara $\mathrm{w}$ moc przedmiotów, które miały bezpośrednią styczność z tatarskim aulija. Wyjaśnieniem tego przypadku mogą być reguły magii sympatycznej, opracowane przed laty przez Jamesa G. Frazera (1969: 37-69). Według teorii klasyka myśli antropologicznej, obecna w tym wypadku może być magia przenośna. Kontakt $\mathrm{z}$ obiektem kultu religijnego zapewnia bowiem przedmiotom okalającym sferę świętości możliwość przekazania na nie cudownej mocy Kontusia. Zasada ta nie mogła być obca Tatarom, ponieważ była powszechnie stosowana $\mathrm{w}$ okresie przedmuzułmańskiego szamanizmu na stepach. Przede wszystkim jednak musiała być im znana w związku ze znaczną popularnością kultu chrześcijańskich relikwii na Kresach. Listki zerwane na mogile, kamyczki lub ziemia pochodząca z grobu mają dla Tatarów właściwość ochronną, gdyż zapewniają poczucie bezpieczeństwa, a także memoratywną jako pamiątka, która przywołuje wspomnienia z wizyty w Łowczycach. O silnej wierze w magiczne właściwości grobu tatarskiego świętego świadczą następujące wypowiedzi:

A tu widzi Pan w modlitewniku mam listek. To nie jest zwykła roślina. Ten listek pochodzi z grobu Kontusia, zerwałam go gdy byliśmy w Łowczycach. W torebce natomiast noszę kamyczek z jego grobu, zawsze jest ze mną [...]. Ja w to wierzę, bo na pewno chroni przed niepomyślnością. Człowiek czuje się bezpieczny. Dla mnie ta moc niezwykła wiąże się z religią, nie zwracałabym na to uwagi, gdybym nie była muzułmanką. Nie wstydzę się tego, że to noszę. W trudnych sytuacjach w życiu mogę czuć się pewnie (W 13a).

Dla mnie to jest ważne, mam wewnątrz tę wiarę w Kontusia. Sama się temu dziwię [...], bo przecież mam wyższe wykształcenie, a wierzę $\mathrm{w}$ to tak samo, jak kiedyś ludzie na Białorusi. Moja mama pochodziła ze Słonimia i wpoiła mi wiele elementów obyczajowych charakterystycznych dla tej tatarskiej ludowości. [...] Przyznam szczerze, że zanim nie pojechałam do Łowczyc, to nie byłam jakoś przekonana, co do cudowności tego miejsca. Dopiero jako dorosła osoba tam pojechałam i ożyły dziecięce wspomnienia. To było bardzo podniosłe przeżycie, tam się czuje specjalne uduchowienie. Aż coś w środku, we wnętrznościach człowieka się dzieje.

\footnotetext{
9 Używane przez Tatarów określenie cmentarza.
} 
Dlatego, za każdym razem gdy tam jestem, to coś ze sobą zabieram. Listek lub kamyk... Te przedmioty ciągle przywołują mi to wspomnienie (W 13b).

Cóż z tego, że ktoś zabrał sobie kamyczek z grobu Kontusia? Jeżeli dobrze się z tym czuje, to chwała Bogu. Przecież nikt o zdrowych zmysłach do kamienia się nie modli! Może to komuś pomoże? Sama świadomość wpływa przecież na nasze samopoczucie i stan zdrowia. Ten kamyczek to po prostu taka pamiątka, starzy ludzie zwracają na to uwagę, dzięki temu ich wiara jest silna, bo może się odwołać do czegoś materialnego, co stale przypomina o świętości (W2).

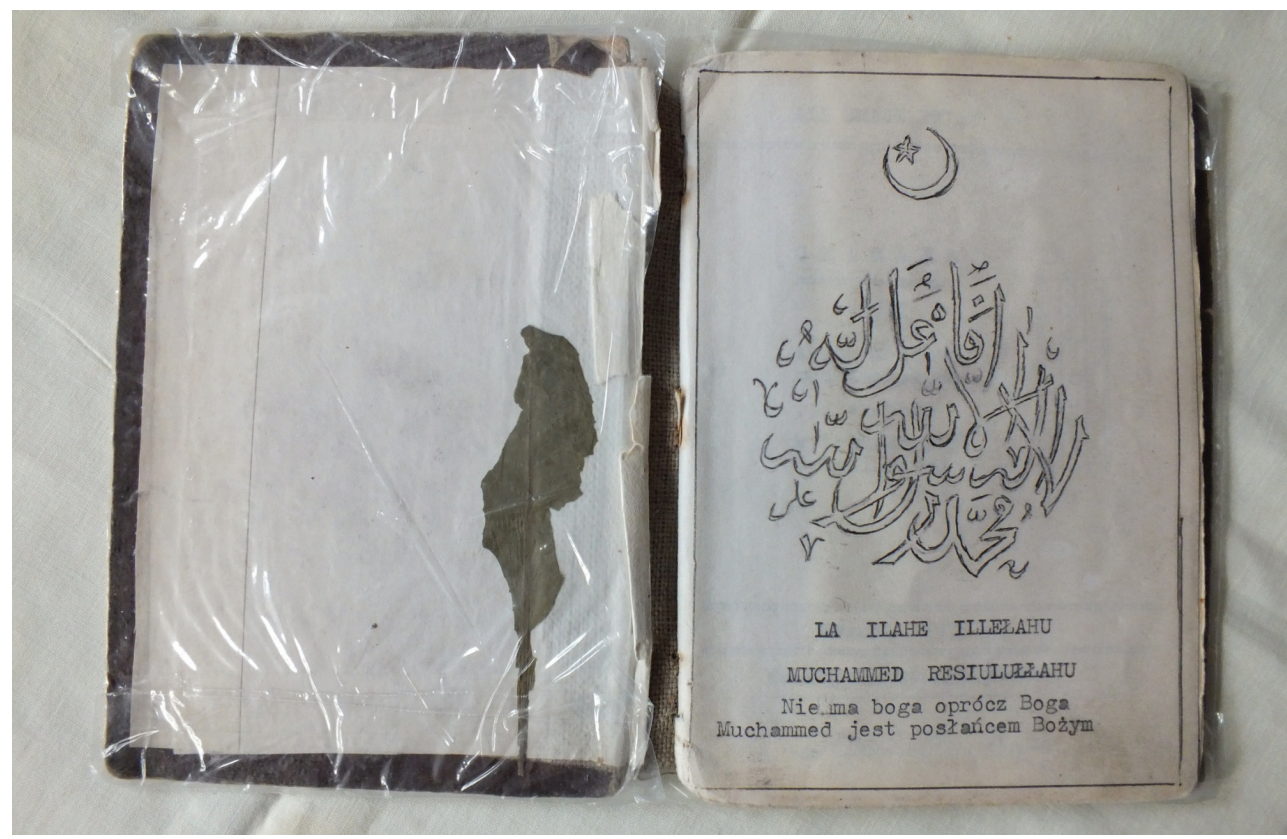

Listek pochodzący z grobu Kontusia w Lowczycach w modlitewniku muzułmańskim (Smajkiewicz 1975) należącym do polskiej Tatarki

\section{Co motywuje Tatarów do pielgrzymowania do grobu Kontusia?}

Respondenci, z którymi przeprowadzono wywiady jednoznacznie stwierdzili, że kult Kontusia stanowił niegdyś swoistą „zastępczą pielgrzymkę”, która miała za zadanie kompensować zaniedbania wymogów nakładanych na wiernych przez Koran i sunnę. Wyjazd do Łowczyc oraz ceremoniał odprawiany przy grobie auliji były przed II wojną światową pojmowane wręcz jako substytut hadżdżu do Mekki, czyli jednego z pięciu głównych filarów islamu ${ }^{10}$. Spostrzeżenia moich rozmówców potwierdza Stanisław Kryczyński, który

10 Obok wspomnianej pielgrzymki do Mekki (hadżdż) głównymi obowiązkami wyznawców islamu są: wyznanie wiary (szahada), codzienna modlitwa (salat), podatek dobroczynny (zakat), post w mieiącu Ramadan (saum). 
pisal, iż w wiekach dawnych (zwłaszcza w XVI w.) pielgrzymowanie do Mekki było dość częste wśród Tatarów będących na służbie królewskiej, natomiast jeszcze w międzywojniu - ze względu na ówczesne trudności komunikacyjne i koszty - należało już do rzadkości, jednakże: „nie mogąc wyprawiać się do dalekiej Arabii, odbywają pobożni Tatarzy pielgrzymki do własnych miejsc świętych: do Łowczyc, aby pomodlić się u grobu świętego pastuszka Kontusia, który cudownym sposobem codziennie przenosił się na modlitwę do grobu Proroka" (Kryczyński 2000: 152). Zwyczaj pielgrzymowania do Łowczyc w miesiącu Ramadan oraz z okazji świąt Ramazan Bajram i Kurban Bajram, choć dziś już rzadki, wpisuje się jednak w specyfikę tatarskiej religijności muzułmańskiej, która przez kilkaset lat ewoluowała na Kresach - z dala od centrów teologicznych islamu - w słowiańskim otoczeniu kulturowym (szerzej Łyszczarz 2013: 193-199). Do problemu odwiedzania Łowczyc jako „zastępczej pielgrzymki” odnoszą się respondenci w słowach:

Kontuś długo zastępował pielgrzymkę do Mekki. Tatarzy udawali się do jego grobu, aby prosić o łaski. Nie każdego było stać, aby pojechać do Mekki. Teraz trudno nam sobie to wyobrazić, bo wsiadamy w samolot, ale kiedyś tak to nie wyglądało (W 7).

Kult Kontusia moim zdaniem rozwinął się zastępczo w stosunku do Mekki. [...] Przyczyną tego było to, że Tatarzy żyjąc w niemuzułmańskim otoczeniu z czasem zatracili znajomość rytuału pięciokrotnej modlitwy. Izolacja od świata islamu zrobiła swoje, ważne były też inne problemy, związane z prozaicznymi kwestiami życia jako mniejszość wyznaniowa. W Polsce chociażby trudno było pościć w Ramadanie tak, jak tego wymaga doktryna [W 1].

Kiedyś rzeczywiście Tatarzy podchodzili do tego, jak do substytutu pielgrzymki. Mekka była praktycznie nieosiągalna, więc jakoś sobie radzono z tym problemem. [...] Jeżeli ktoś w Mekce nie był, to na pewno odczuwa brak z tego powodu. Każdy wierzący muzułmanin tak ma [...]. Na pewno wyjazd do Łowczyc nikomu nie zastąpi pielgrzymki do Mekki, ale jeżeli nie ma możliwości odbycia hadżdżu to dobrze, że chociaż jest ten Kontuś (W 2).

Tatarscy rozmówcy podkreślają, że obecnie - kiedy wyjazd do Mekki przestał być nieosiągalny ${ }^{11}$ - modlitwa przy grobie Kontusia stanowi często mistyczne przeżycie, które konfrontowane jest z doświadczeniem „prawdziwego” hadżdżu. Co ciekawe, w przypadku cytowanych poniżej wypowiedzi, przekonanie o wyjątkowości Łowczyc utrzymuje się nawet wśród osób, które wcześniej odbyły pielgrzymkę do Mekki.

Wizyta w Łowczycach na pewno była dla mnie ważna, modliłem się przy grobie [...]. Było to jakieś przeżycie mistyczne, $\mathrm{z}$ tym że nie wiem, na ile autentyczne, a na ile związane $\mathrm{z}$ autosugestią. Jadąc tam miałem przecież jakieś oczekiwania, wyobrażałem sobie to miejsce. Dziś nie jestem w stanie obiektywnie tego ocenić. [...] Dla moich białoruskich przyjaciół było to głęboko religijne doświadczenie. Ja już [...] byłem w Mekce i na świętość Kontusia patrzyłem przez pryzmat «prawdziwego» hadżdżu [W 1$]$.

[...] byłam już tam (w Łowczycach - przyp. M.E.) dobrych kilka razy. Pierwszy raz w latach 70., potem dość często jeździłam w latach 90., obecnie rzadziej, bo zdrowie nie pozwala. Byłam w Mekce, więc patrząc na ten grób przypominam sobie tę moją pielgrzymkę (W 4).

To jest legenda z moich lat dzieciństwa. Traktuje ją jako taką przypowieść o podróży do Mekki. Jako dziecko zastanawiałem się, jak jest w Mekce, bardzo chciałem odbyć pielgrzym-

11 Od początku lat 90., każdego roku, na pielgrzymkę do Mekki wyjeżdża kilkoro polskich Tatarów. Ich wyjazd koordynuje MZR, który zgłasza kandydatury pielgrzymów. Stroną finansową zajmuje się Arabia Saudyjska, czasem także wsparcia udzielają międzynarodowe organizacje muzułmańskie. 
kę. Fascynował mnie ten motyw przewodni legendy, który mówi o spotkaniu Łowczyckiego z Kontusiem w Mekce. To magiczne przenoszenie się z miejsca na miejsce działało na moją wyobraźnię. Ta legenda była jak baśń, w sam raz pasowała do wrażliwości dziecka. [... ] Dokładnie już nie pamiętam, kto mi po raz pierwszy opowiedział legendę. Chyba to była babcia. [...] Kiedy byłem na pielgrzymce w Mekce, te dziecięce wspomnienia ożyły (W 11).

Respondenci uczestniczący w badaniach, z całą mocą podkreślają, że współcześnie Tatarzy mają świadomość różnic - w sensie doktrynalnym - istniejących pomiędzy Mekką a Łowczycami. Konstatację tę potwierdza przekonanie, iż pielgrzymuje się do Mekki, natomiast grób auliji tylko się „odwiedza”. W podobny sposób jeden z rozmówców zwrócił uwagę, że tytuł hadżiego nadawano kiedyś tym osobom, które były w Mekce. Status religijny Łowczyc, jako miejsca odwiedzin grobu świętego, był zatem znacznie niższy niż świętego miasta islamu.

Tatarzy, co by o nich nie mówić, choć mieli braki w wiedzy religijnej, to kwestie elementarne znali. Wiedzieli zatem, że pielgrzymuje się tylko do Mekki, tylko to rozumiemy pod pojęciem hadżdżu i umry, ale jeżeli ten cały rytuał nazwiemy po prostu «odwiedzaniem grobu auliji Kontusia» to problem znika. Myślę, że tak to wyglądało: pielgrzymka kieruje się do Mekki, natomiast groby auliji się tylko odwiedza (W 5).

Dla niektórych na pewno wizyta w Łowczycach była pielgrzymką, która uspakajała sumienie. Tytuł hadżiego nadawano jednak tylko tym, którzy byli w Mekce. Tatarzy wiedzieli więc, że to nie jest to samo (W 6).

Byłem w Łowczycach, pojechałem na otwarcie meczetu. Dla mnie odwiedziny grobu Kontusia nie były pielgrzymką. Nie mieści mi się to w doktrynie religijnej. Nie ma czegoś takiego, jak substytut hadżdżu. Nie można Mekki zastąpić Łowczycami. Ja rozumiem, że kiedyś ludzie byli biedni, a podróż trudna i niebezpieczna. Poziom wiedzy religijnej był też taki, jaki był. Dziś jednak, w XXI wieku, nie da się mówić o odwiedzinach grobu Kontusia jak o pielgrzymce (W 12).

Pomijając, historyczny już dziś, motyw wyjazdu do Łowczyc jako „zastępczego hadżdżu”, chęć odwiedzenia grobu Kontusia respondenci wyjaśniają w sposób bardzo ogólny. W zebranych wypowiedziach pojawia się bowiem opinia, wedle której pielgrzymowanie stanowi uniwersalną potrzebę człowieka, realizowaną często indywidualnie i w wymiarze lokalnym. Przyjazd do Łowczyc może również wynikać, z wydawałoby się, tak błahej pobudki, jak ciekawość.

W każdej religii znajdziesz motyw pielgrzymki. To wynika z natury człowieka. [...] Pielgrzymuje się tam gdzie jest obecna atmosfera świętości. Oczywiście sanktuaria mają różną rangę, mogą być wielkie jak Mekka, ale są też tak małe jak Łowczyce (W 5).

Są też tacy, którzy przyjeżdżają z ciekawości jak to jest, bo coś o Kontusiu słyszeli (W 4).

Niezwykle interesującą przyczynę, która motywuje - a na pewno kiedyś motywowała - Tatarów do pielgrzymowania do grobu Kontusia, stanowi ponadto wiara w uzdrawiającą moc wizyty w Łowczycach. Na Kresach Wschodnich, ze względu na ograniczony dostęp do profesjonalnych metod leczniczych, bardzo popularna była przed laty medycyna niekonwencjonalna. Brak wiedzy o istocie i przyczynach chorób, a także silna religijność lokalnych społeczności powodowały powszechne przekonanie o tym, że wpływ na zdrowie ma obecność duchów, które mogą szkodzić człowiekowi. W społeczności tradycyjnej, którą 
niewątpliwie byli Tatarzy, w przypadku najcięższych schorzeń, obok wykorzystywania znanych od wielu pokoleń leczniczych właściwości ziół i innych roślin, a także odczyniania uroków przez znachorów (siufkaczy, szeptuch), istniała ponadto silna wiara w moc religii, która dopuszczała możliwość zaistnienia cudu uzdrowienia. O ile praktyki lecznicze tatarskich znachorów w zasadzie nie są już stosowane, co więcej zostały prawie zupełnie zapomniane ${ }^{12}$, o tyle wiara w uzdrawiającą moc mogiły Kontusia jest nadal obecna. Dla polskich Tatarów, ten ewidentny przejaw myślenia magicznego, nierozerwalnie wiąże się z głęboką religijnością. Według respondentów wstawiennictwo tatarskiego auliji często, pomimo postępu medycyny, jest ostatnią deską ratunku. O rzekomej skuteczności tych zabiegów świadczyć mogą relacje, w których przywoływane są przypadki uzdrowienia:

Na pewno przyjeżdżają do Łowczyc przekonani o tym, że to jest cudowne miejsce. Nawet jeżeli za bardzo religijni nie są, to wychodzą z założenia, że może pomoże, a na pewno nie zaszkodzi. Albo się idzie z potrzeby serca, albo na wszelki wypadek. [...] Modlitwa w tym miejscu ma znaczenie dla duszy Kontusia. [... ] przez modlitwę spełniają się życzenia tych, którzy ją odmawiają. Wizyta na tym cmentarzu może pomóc, ludzie modlą się o zdrowie (W 4).

Moja mama wspominała tylko, że gdzieś na Białorusi jest taki cudowny grób, którego świętość polegała na tym, że jeżeli coś człowiekowi dolega i tam się pomodli, to zostanie uzdrowiony. [...] Tatarzy pielgrzymowali przede wszystkim dlatego, że wierzyli, że Kontuś im pomoże. To tak samo jak w Kościele: «gdy trwoga to do Boga». Ludzie proszą świętych o pomoc, bo liczą na ich wstawiennictwo (W 6).

Chciałbym tam kiedyś pojechać, pomodlić się tak, jak robili przodkowie, tak jak mama to widziała. [...] Tym, co spowodowałoby mój wyjazd do Łowczyc, byłaby chyba wiara w to, że odwiedzenie mogily Kontusia może przynieść zdrowie. [... ] Coś w tym jest, że ludzie z okolicy tam zjeżdżają. Moja ciotka miała bóle szczęki, strasznie ją bolało, żaden dentysta nie mógł pomóc. Odkąd pojechała do Łowczyc, to choroba jej przeszła. Kilka zębów wprawdzie wypadło, ale do dentysty nie musiała chodzić. Słyszałem też o Tatarach, którzy nie mieli dzieci, pojechali do Łowczyc i są już szczęśliwymi rodzicami [W 7].

\section{Zakończenie}

Kontuś z Łowczyc - pomimo ograniczonej świadomości istnienia tej postaci - zajmuje poczesne miejsce $\mathrm{w}$ dziedzictwie polskich Tatarów. Tradycja ta zapewne nie przetrwałaby, gdyby nie nastąpiło utrwalenie ludowej legendy w pracach Michała Dmitriewa spopularyzowanych przez przedwojennych tatarskich działaczy społeczno-kulturalnych. Fenomenem tego kresowego auliji był na pewno fakt jego wyjątkowości, o czym wspominał jeden z respondentów: „To nie jest przypadek, że pamięć o nim przetrwała. [... ] Tak jak Mekka jest jedna, tak Kontuś był jeden. Innych świętych nie znamy” [W 2].

Ten sam rozmówca - podkreślając fakt tego, że Kontuś jest jedynym tatarskim świętym - konkludowal ponadto, że: „Tatarzy nie mogli mieć wielu alternatywnych miejsc do pielgrzymowania, bo uległyby one deprecjacji” [W 2].

12 W przypadku społeczności tatarskiej wypędzanie złych mocy odbywało się poprzez zamawianie modlitwą (odpiewanie), któremu towarzyszyło dmuchanie na chorego (siufkanie), okurzanie go dymem, a także obmywanie uświęconą wodą lub jej picie (szerzej: Łyszczarz 2017c: 96-99). 
Postać Kontusia, unikatowego tatarskiego auliji, jest bardzo mocno osadzona w ludowej pobożności, w której wiara religijna ma mistyczny charakter, wiążący się z poszukiwaniem cudowności. W tym kontekście wydaje się, że tatarscy muzułmanie potrzebowali swojskiego i prostego wzoru do naśladowania. Kimś takim mógł być zapewne Kontuś. Wskazują na to słowa respondenta: „Kontuś wyróżniał się tym, że był silniejszy od innych ludzi. To jest wzór do naśladowania. Skromny, biedny pastuszek, a obdarzony został łaską przez Boga” [W 13b].

Na zakończenie niniejszych rozważań warto dodać, że tatarscy rozmówcy mają świadomość tego, że o ile w Polsce tradycja związana z Kontusiem jest praktycznie zapomniana i trudno mówić o jej obecności w postaci mitu, o tyle na Białorusi sytuacja wygląda inaczej. Zdaniem respondentów zachowaniu pamięci o łowczyckim świętym u naszych wschodnich sąsiadów, sprzyjała specyficzna sytuacja tego kraju. W słabo zurbanizowanym, rolniczym państwie, w o wiele większym stopniu niż miało to miejsce w Polsce, przetrwać mógł międzypokoleniowy przekaz tradycji. Na Białorusi wolniej zachodzą też zmiany cywilizacyjne, związane z m.in. ze skutkami rozwoju gospodarczego i ekspansją kultury popularnej. Kraj ten, jak zauważają rozmówcy, jest w znacznym stopniu odizolowany od wpływów globalizacji i nowoczesności. Mając na względzie własne doświadczenia, z pewną dozą sentymentu, Tatarzy konstatują, iż anachroniczność Białorusi ogranicza proces degradowania roli tradycji w życiu człowieka.

Tam (w Łowczycach - przyp. M.Ł.) to przetrwało, bo na Białorusi dłużej dominował ten ustny przekaz tradycji. To co u nas po wojnie zniknęło, tam nadal było obecne (W 4).

Oni tam (na Białorusi - przyp. M.Ł.) ciągle żyją trochę inaczej niż my. Czas wolniej płynie, nie ma tej pogoni za pieniądzem i rozrywką jak u nas (W 6).

Tam (na Białorusi - przyp. M.Ł.) jeszcze nowoczesność nie zawitała w tak silnym stopniu jak u nas. Żyją sobie na wsi, odizolowani od świata. Pod tym względem Łukaszenka im się udał (W 7).

Informacje dotyczące białoruskiej rzeczywistości, uzyskane od polskich Tatarów, wymagają weryfikacji poprzez pogłębione badania terenowe. Pełną wiedzę o stanie zachowania pamięci o Kontusiu przynieść bowiem może tylko wizyta w Łowczycach i rozmowy $\mathrm{z}$ tamtejszymi Tatarami.

\section{Bibliografia}

Chazbijewicz, Selim 2012. Baśnie, podania i legendy polskich Tatarów. Białystok: Muzułmański Związek Religijny w RP.

Czachorowski, Musa Çaxarxan 2018. Pamięć. Wrocław: Inicjatywa Wydawnicza Çaxarxan Xucalıq, Muzułmański Związek Religijny w RP.

Dmitrijew, Michaił 1859. „Sobranije dalniejszych istoriczeskich swiedienij o Nowogrudkie so smierti Swientoroga (1270)". Wiestnik impieratorskogo Russkogo gieograficzeskogo obszczestwa 26, 2: 66-67.

— 1861a. „Priedanija o Łowczicach”. Wilenskij wiestnik (Kuryer Wileński) 13: 111 [z dnia 14.02].

_ 1861b. „Eowczyce, Mekka Litewska”. Czas 69: 3 [z dnia 23.03]. 
Drozd, Andrzej 2016. „Corpus Inscriptionum Tartatorum Poloniae et Lithuaniae”. T. 1: Studzianka. Warszawa: Polskie Towarzystwo Orientalistyczne.

Faizof, Fajaz 2011. Saga o Kontusiu. Sokółka: Związek Tatarów RP.

Frazer, James George 1969. Złota gałą́. Studia z magii i religii. Warszawa: PWN.

Kryczyński, Stanisław 2000. Tatarzy litewscy. Próba monografi historyczno-etnograficznej. Gdańsk: Związek Tatarów Polskich.

Łyszczarz, Michał 2013. Młode pokolenie polskich Tatarów. Studium przemian generacyjnych młodzieży w kontekście religijności muzutmańskiej oraz tożsamości etnicznej. Olsztyn-Białystok: Katedra Socjologii UWM, Muzułmański Związek Religijny w RP.

_ 2017a. „Etniczność a status mniejszościowy - przypadek polskich Tatarów.” W: Tomasz Gajownik [\&] Paweł Pietnoczka [\&] Krzysztof Sidorkiewicz (red.). Dialog kultur czy zarzewie konfliktów - problematyka mniejszości narodowych w Europie. Olsztyn: Wydawnictwo Uniwersytetu Warmińsko-Mazurskiego w Olsztynie.

— 2017b. „Położenie i status prawny polskich Tatarów po 1945 roku”. W: Piotr J. Krzyżanowski [\&] Aleksander Miśkiewicz [\&] Beata A. Orłowska (red.). Tatarzy w Polsce po 1945 roku. Historia. Religia. Tożsamość. Gorzów Wielkopolski: Wydawnictwo Naukowe Akademii im. Jakuba z Paradyża.

— 2017c. „Zabiegi lecznicze znachorów oraz czarna magia w tradycji etnicznej polskich Tatarów”. W: Adam Janczyk [\&] Julia Doroszewska [\&] Karolina M. Hess (red.). Czarownice. Studia $z$ kulturowej historii fenomenu. Katowice: Wydawnictwo Sacrum.

— 2017d. „Znaczenie kultu Kontusia z Łowczyc dla polskich Tatarów - historia i współczesność” W: Artur Konopacki (red.). Tożsamość a religia Tatarów Wielkiego Księstwa Litewskiego. Bialystok: Związek Tatarów RP.

Malinowski, Bronisław 1990. Mit, magia, religia. Dzieła tom VII. Warszawa: Państwowe Wydawnictwo Naukowe.

Tyszkiewicz, Jan 1986. Tatarzy na Litwie i w Polsce. Studia z dziejów XIII-XVIII w. Warszawa: Państwowe Wydawnictwo Naukowe.

Vorbrich, Ryszard 2009. „Pielgrzymka do grobu Ewliji Konteja (Kontusia) w kontekście globalnym i lokalnym". W: Selim Chazbijewicz (red.). Tatarzy - historia i kultura. Sesja naukowa. Szreniawa, 26-27 czerwca 2009. Szreniawa: Muzeum Narodowe Rolnictwa i Przemysłu Rolno-Spożywczego.

Wnuk-Lisowska, Elżbieta 2013. Islam. Między herezją a ortodoksją. Kraków: Wydawnictwo Uniwersytetu Jagiellońskiego. 